International Journal of Agriculture, Environment and Bioresearch

Vol. 4, No. 06; 2019

ISSN: $2456-8643$

\title{
GROWTH PERFORMANCE AND TOLERANCE OF JATROPHA CURCAS IN SPENT OIL CONTAMINATED SOIL
}

\author{
Oyedeji, M.B ${ }^{1}$, Bankole, S.O' ${ }^{2}$ Bolanle-Ojo, O.I ${ }^{2}$ and Aina, O.O \\ ${ }^{1}$ Vocational Studies Department, Federal College of Forestry, Ibadan. \\ ${ }^{2}$ Bioscience Department, \\ ${ }^{3}$ Forest Conservation and Protection Department \\ Forestry Research Institute of Nigeria, Ibadan
}

http://doi.org/10.35410/IJAEB.2019.4459

\begin{abstract}
This study investigated the growth response of Jatropha curcas and its potential in the phytoremediation of soil contaminated with spent oil in a two (2) months pot experiment. Two (2) $\mathrm{kg}$ of potted top soil collected within Federal college of Forestry, Ibadan premises was contaminated with varying volume (treatment) of spent oil (T1-0ml, T2-50ml, T3-150ml and T4$250 \mathrm{ml}$ ) replicated five (5) times, seedlings of Jatropha curcas were transplanted into the pots and growth parameters such as plant height, stem girth and number of leaves was measured on weekly basis for eight (8) weeks, while pre planting and post planting total petroleum hydrocarbon (TPH) concentration of the soil was determined using standard methods and compared. The result shows a pre planting TPH of $0.57 \%, 3.23 \%, 13.00 \%$ and $17.57 \%$ for treatments 1,2, 3 and 4 respectively, while comparable growth rate in plant height was observed across the treatments with T2 having the highest height after 8 weeks while T3 had the least height. No significant difference between the treatments at $\mathrm{p}<0.05$; in stem girth, T1 had the highest while T3 had the least which is not significantly different at $\mathrm{p}<0.05$; while treatments 1 , 2 and 4 had comparable number of leaves which is significantly different from T3 which had the lowest number of leaves. Jatropha curcas contributed to a significant removal of $82.45 \%$, $69.65 \%, 86.54 \%$ and $86.57 \%$ of TPH present in the pre-planting soil from T1, T2, T3 and T4 respectively. The study further confirms the ability of Jatropha curcas to withstand adverse condition and could thus be candidate for the phytoremediation of oil spill soils.
\end{abstract}

Keywords: Spent Oil; Hydrocarbon; Phytoremediation; Candidate.

\section{INTRODUCTION}

In Nigeria, there is a significant spillage of oil into the environment from a number of sources including damaged oil tankers, storage vehicles, leakages of oil pipelines, oil tankers overflow [1], [2] due to increase in crude oil exploration, exploitation, storage and transportation . This is because oil is the life wire of the Nigerian economy [3] and accounts for over $90 \%$ of the national income [4]. Significant among the damages done to the environment by crude oil spills is pollution of soil which renders it less useful for agricultural activities and affects soil dependent organisms adversely [5]. Pollution of agricultural soil has in turn significantly affected the growth performance of plants. [6] reported that contamination of soil with crude oil 
significantly reduced biomass accumulation in Jatropha curcas when compared to seedlings grown in uncontaminated subplots. He also observed a negative interaction between soil crude oil level and weight gain in the plants. In an earlier study, [7] reported that spent engine oil affected percentage germination, days to germination and rate of germination in six cultivars of cowpea. Therefore this study aims at assessing the growth performance and tolerance of Jatropha curcas in spent oil contaminated soil.

\section{MATERIALS AND METHODS}

\section{Study Area}

The pot experiment was conducted at the Federal College of Forestry, Ibadan $\left(7^{\circ} 23^{\prime} \mathrm{N} 3^{\circ} 51^{\prime} \mathrm{E}\right)$ between April and June 2016, the climatic condition of the area is tropical and dominated by rainfall pattern of $1400 \mathrm{~mm}-1750 \mathrm{~mm}$ with average humidity of about $80-85 \%$.

\section{Materials}

Spent lubricating oil used to contaminate the soil was obtained from mechanic workshop, seedlings of Jatropha curcas, polythene pots, paper tape, hand trowel watering cans, and toluene (Analar grade).

\section{Soil Sampling and Treatment}

Top soil $(0-15 \mathrm{~cm})$ was collected from Teak plantation of the Federal College of Forestry, sieved through $2 \mathrm{~mm}$. The growth media was prepared using soil with varying levels of spent oil volume, where T1 (Control, $2 \mathrm{~kg}$ of the soil $+0 \mathrm{ml}$ spent oil), T2 ( $2 \mathrm{~kg}$ of soil $+50 \mathrm{~m}$, spent oil), T3 $(2 \mathrm{~kg}$ of soil $+150 \mathrm{ml}$ spent oil) and T4 $(2 \mathrm{~kg}$ of soil $+250 \mathrm{ml}$ spent oil). The contaminated soils were air dried for $24 \mathrm{hrs}$ with representative samples from each treatment pot analysed for Total petroleum hydrocarbon (TPH) before planting and after harvesting.

\section{Determination of Total Petroleum Hydrocarbon}

Total Petroleum Hydrocarbon was determined gravimetrically by toluene cold extraction method as described by Adesodun and Mbagwu, [8]. 10g of soil sample was weighed into 50ml flask; 20ml of toluene (Analar grade) was added. After shaking for 30mins on an orbital shaker, the liquid phase of the extract was measured spectrophotometrically at $420 \mathrm{~nm}$. The total petroleum hydrocarbon (TPH) in each sample was estimated with reference to standard curve derived from fresh spent lubricating oil with toluene.

\section{Test Plant/Experimental Design}

Healthy seedlings of Jatropha curcas were obtained from the central nursery of Forestry Research Institute of Nigeria (FRIN). The seedlings were transplanted into the prepared pots with different treatments and arranged in a Completely Randomized Design (CRD) and replicated five (5) times. Watering was done daily and data taken

\section{Data Collection}


Vol. 4, No. 06; 2019

ISSN: $2456-8643$

Growth parameters like plant height measured using metre rule, stem diameter measured using a vernier calliper and number of leaves produced done by visual count were measured to access the tolerance of test plant in spent oil. All were measured from two weeks after transplanting.

Total petroleum hydrocarbon of the treated soil samples was also analysed before planting and after harvesting and compared to access the tolerance ability of the test plant.

\section{Statistical Analysis}

Analysis of variance was done to identify significant difference between the treatments in the growth parameters while Duncan test was used to separate the mean. Also student's t-test was done to determine significant difference between TPH in the soil before planting (after treatment) and TPH in the soil after harvesting.

\section{RESULTS AND DISCUSSION}

\section{Results of Pre-planting Soil Analysis}

The pre-planting soil analysis shows a Total Petroleum Hydrocarbon (TPH) of $0.57 \%, 3.23 \%$, $13.00 \%$ and $17.57 \%$ for treatments $1,2,3$ and 4 respectively showing a dose dependent increase in the TPH levels on addition of various volumes of spent oil into the soil, no observable trend was observed in the initial pH of 5.66 (T1), 5.56 (T2), 5.74 (T3) and 5.41 (T4).

\section{Growth Parameter}

Figure 1 presents the weekly trend observed in plant heights of transplanted Jatropha curcas seedling as affected by various levels of spent lubricating oil. At the end of eight weeks, no significant difference $(\mathrm{p}<0.05)$ was observed in plant heights of all the treatments with treatment $2(50 \mathrm{ml}$ spent oil) having the highest height of $30.24 \mathrm{~cm}$ and treatment $3(150 \mathrm{ml}$ spent oil) having the least of $24.09 \mathrm{~cm}$. This observation is contrary to the findings of Idowu and Fayinminnu, [3] where the control shows a significant increase in plant height compared to other treatments in their study of phytoremediation of spent oil using Jatropha curcas. This observed difference may be due to the widely documented fact about Jatropha curcas being able to thrive in adverse soil condition as similar studies using Jatropha curcas to phytoremediate heavy metals from sewage sludge follows similar trend observed in this study in terms plant heights $[10,11]$.

Figure 2 shows the observed growth trend in terms of stem girth, no significant difference (p < 0.05 ) was observed between the treatments after eight (8) weeks. Treatment 1 (control) had the highest stem girth of 4.64 while T3 had the least 3.10, thus, spent lubricating oil toxicity may have impacted the stem girth of Jatropha curcas, albeit not significantly.

From the data obtain for number of leaves (Figure 3), treatment 3 produced the lowest number of leaves after eight (8) weeks which is significantly different $(\mathrm{p}<0.05)$ from the other treatments, while treatment 2 significantly produced the highest number of leaves. Treatment 4 produced comparable number of leaves with the control, this is contrary to the findings of [3] where increased dosage of spent lubricating oil caused a reduction in the stem girth of Jatropha curcas. 


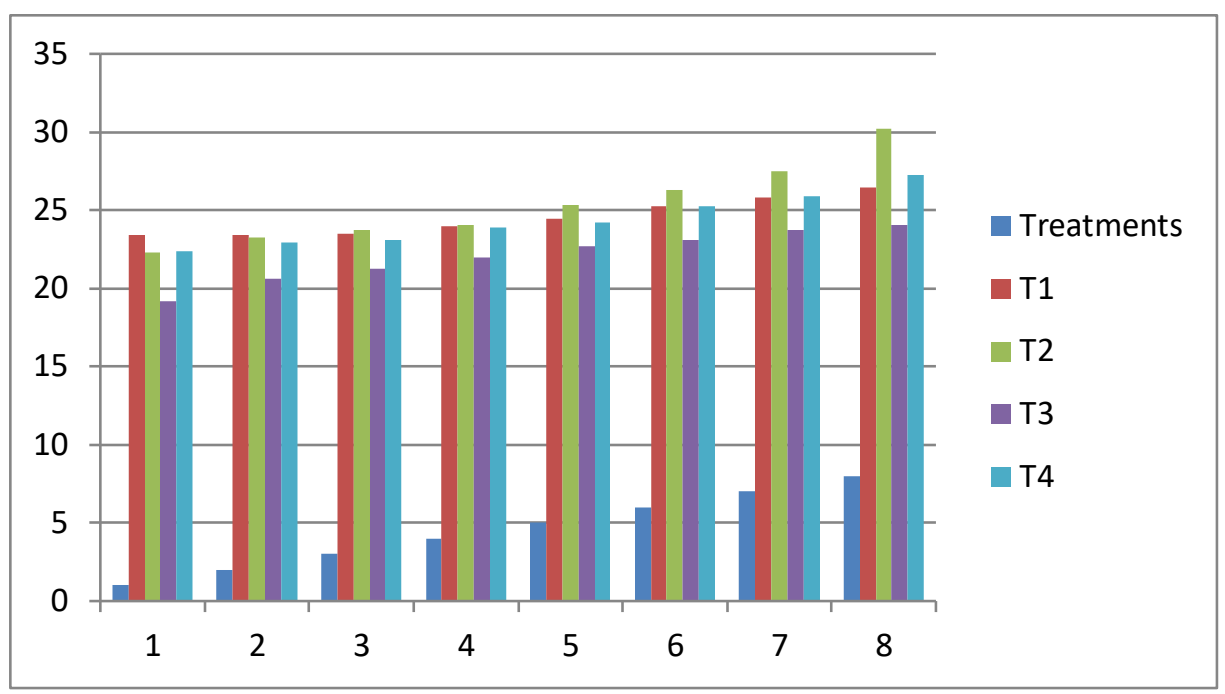

Figure 1. Weekly Trend in Plant Height as Affected by Spent Lubricating Oi

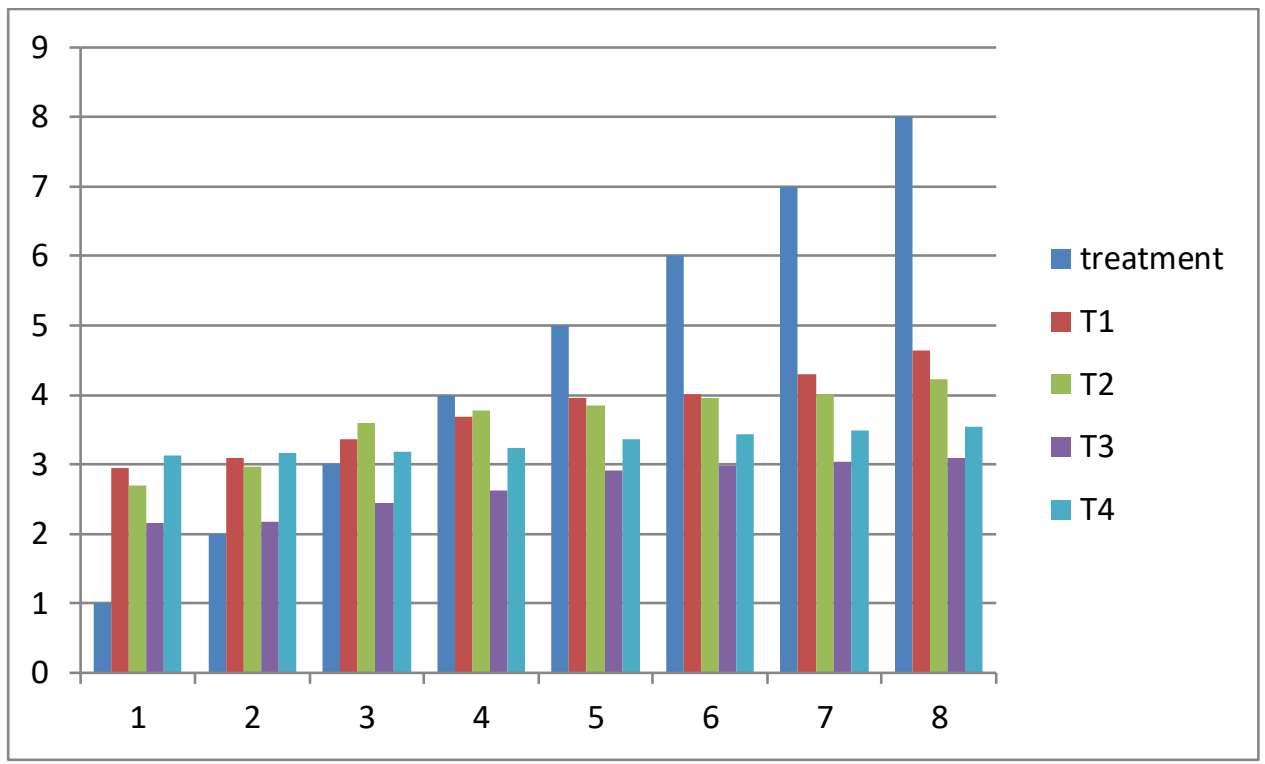

Figure 2. Weekly Trend in Stem Girth as Affected by Spent Lubricating Oil 


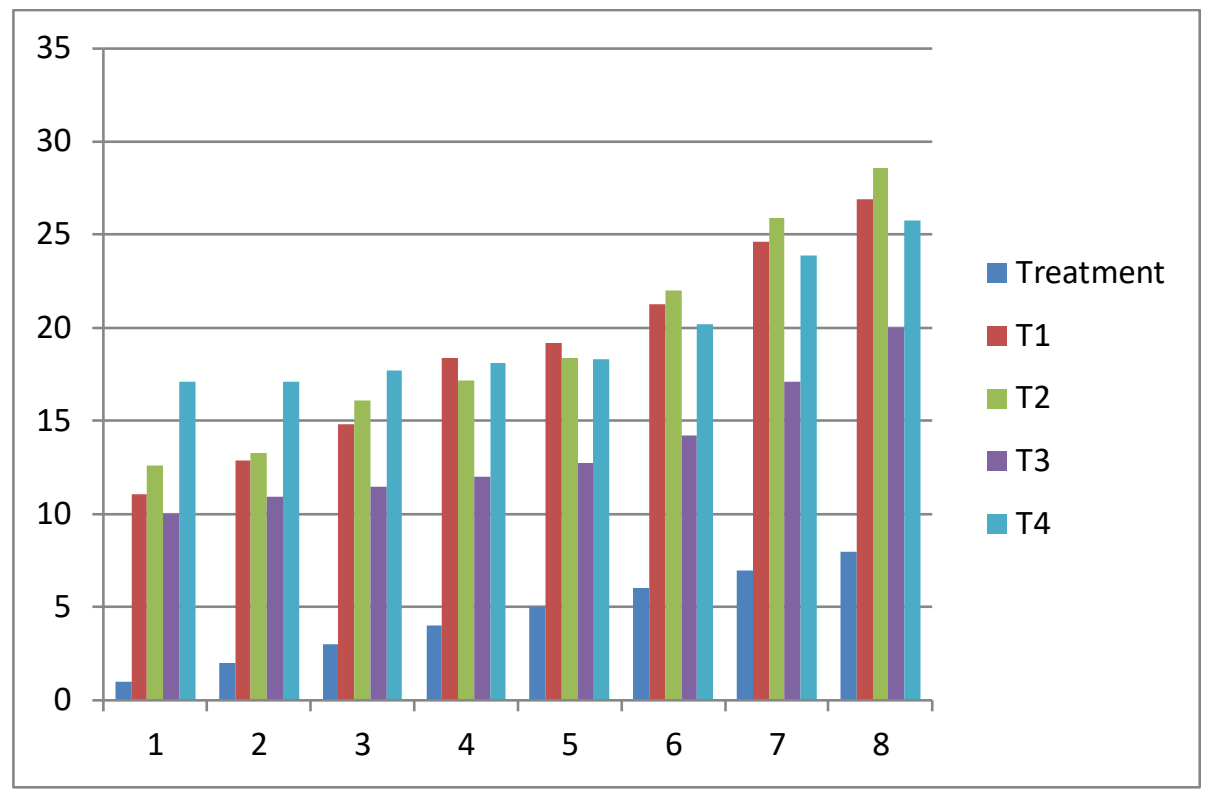

Figure 3. Weekly Variation in Number of Leaves as Affected by Spent Lubricating Oil (Points with same alphabet are not significantly different from each other at $\mathrm{p}<0.05$ )

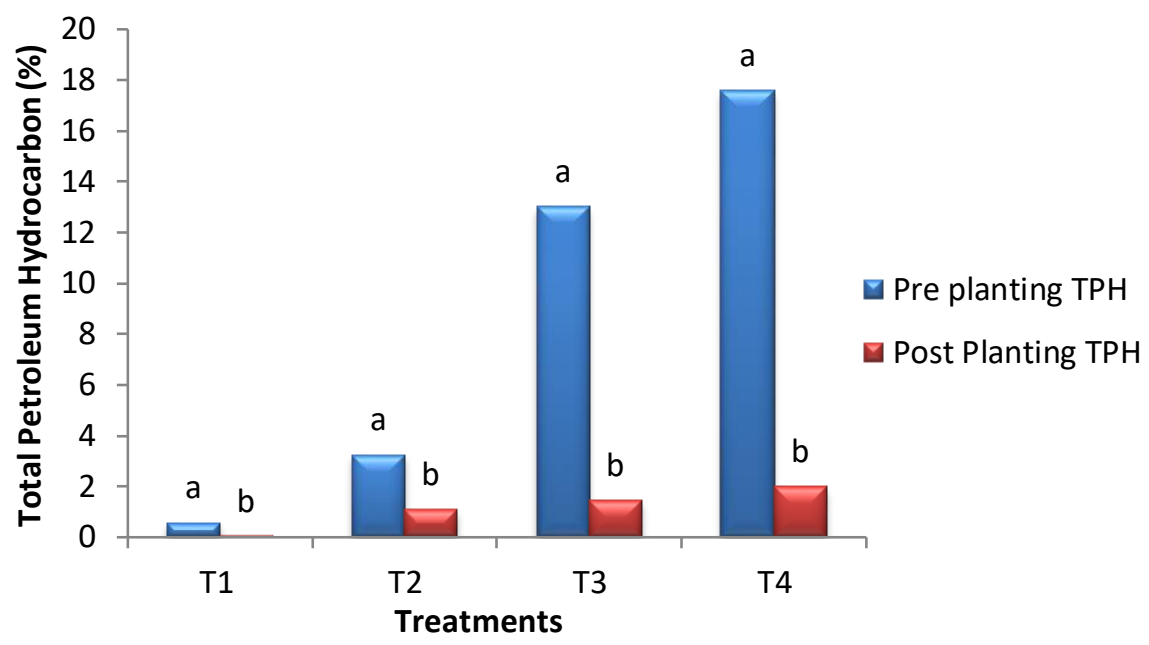

Figure 4. Comparative TPH in Pre-planting and Post-Planting Soil (Complementary bars with same alphabet are not significantly different from each other at $p<0.05$ )

\section{Total Petroleum Hydrocarbon Concentration in Growth Media}

The measurement of amounts of spent lubrication oil in soil was done through quantitative analyses of total petroleum hydrocarbon (TPH) concentration in the soil, the pre-planting soil TPH was $0.57 \%, 3.23 \%, 13.00 \%$ and $17.57 \%$ for Treatments $1,2,3$, and 4 respectively. At the end of the study, the post planting soil TPH was compared using student's t-test as shown in Figure 4. The results shows a significant difference between the pre-planting soil TPH and post- 
planting soil TPH across all the treatment, thus, Jatropha curcas significantly remove $82.45 \%$, $69.65 \%, 86.54 \%$ and $86.57 \%$ from $\mathrm{T}_{1}, \mathrm{~T}_{2}, \mathrm{~T}_{3}$ and $\mathrm{T}_{4}$ respectively. This may suggests the potential of Jatropha curcas to absorb some of the spent oil from the soil.

\section{CONCLUSION AND RECOMMENDATION}

The study has indicated the ability of Jatropha curcas to survive high level of spent oil in the soil, at the end of the study period. Treatment 2 gave the best response in plant height, stem girth and number of leaves while Treatment 3 had the least performance in the growth parameters thus, the growth response in this study was not dose dependent as reported by some researchers in previous studies. Total Petroleum Hydrocarbon drastically decreased from the growth media across all the treatment which appears to shows dose dependent removal efficiency.

The study further shows the ability of Jatropha curcas to withstand adverse soil condition and could thus be a candidate for the phytoremediation of oil spill soils. It is therefore recommended that Jatropha curcas should be further explored as a good candidate for the cleanup of spent oil contaminated soil, and also, due to the massive removal of soil TPH observed, the role of carbon degrading microorganisms in this process cannot be rule out this, further studies on the microbial degradation alongside plant uptake needs to be evaluated as well as the accumulation of petroleum hydrocarbon in the plant's tissue.

\section{REFERENCES}

1. Agamuthu, P., Abioye, Peter O and Aziz, A. A. (2010). Phytoremediation of soil contaminated with used lubricating oil using Jatropha curcas. Journal of Hazardous Materials, 179(1-3), 891-4.

2. Adegeye, A. O., Ayodele, L. A. \& Ufito, L. A. (1993). Effect of oil exploration on the forest and wildlife resources in Delta State of Nigeria. Proceedings of Foresters Association of Nigeria, Ikeja, Lagos, 45-52.

3. Agbogidi, O. M. (2010). Screening six cultivars of cowpea (Vigna unguiculata (L) Walp) for adaptation to soil contaminated with spent engine oil. Academic Arena, 2(4), 33-40.

4. Agbogidi, O. M. (2011). Effects of crude oil contaminated soil on Biomass accumulation in Jatropha curcas L. seedlings. Journal of Ornamental and Horticultural Plants, 1(1), 43-49.

5. Uchendu, Udochukwuka Ifeanyi and Ogwo, P. A. (2014). The Effect of Spent Engine Oil Discharge on Soil Properties in an Automobile Mechanic Village in Nekede, Imo State , Nigeria. Journal of Environmental Science, Toxicology and Food Technology, 8(11), 28-32.

6. Idowu, O. D. and Fayinminnu, O. O. (2015). Phytotoxicity Effect of Spent Oil on Jatropha curcas Seedlings Used in Soil Phytoremediation. Ethiopian Journal of Environmental Studies \& Management, 8(Suppli. 2), 906-915.

7. Stephen, E. and Ijah, U. J.. (2011). Comparison of Glycine Max and Sida Acuta in the Phytoremediation of Waste Lubricating Oil Polluted Soil. Nature and Science, 9(8), 190-193.

8. Oyem, Isama Lawrence Rank and Oyem, I. L. (2013). Effects of Crude Oil Spillage on Soil Physico-Chemical Properties in Ugborodo Community. International Journal of Modern Engineering Research (IJMER), 3(6), 3336-3342. 
9. Udoh, B. T., \& Chukwu, E. D. (2014). Post-Impact Assessment of Oil Pollution on Some Soil Characteristics in Ikot Abasi, Niger Delta Region, Nigeria. Journal of Biology, Agriculture Healthcare, 4(24), 111-120.

10. Moses, E. A., \& Uwah, E. I. (2015). The effect of crude oil pollution on some soil fertility parameters in Ikot Obo Oboreyin, Ikot Abasi, Akwa Ibom State, Nigeria. Merit Research Journal of Environmental Science and Toxicology, 3(2), 17-24.

11. Kuo, H. C., Juang, D. F., Yang, L., Kuo, W. C. and Wu, Y. M. (2014). Phytoremediation of soil contaminated by heavy oil with plants colonized by mycorrhizal fungi. International Journal of Environnmental Science and Technology, 11, 1661-1668.

12. Dhamodaran, T. K., \& Chacko, K. C. (1999).

13. Maryam, G., Majid, N. M., Islam, M. M., Ahmed, O. H. and, \& Abdu, A. (2015). Phytoremediation Of Copper-Contaminated Sewage Sludge By Tropical Plants. Journal of Tropical Forest Science, 27(4), 535-547.

14. Adesodun, J. K. and Mbagwu, J. S. C. (2008). Biodegradation of waste lubricating petroleum oil in a tropical alfisol as mediated by animal droppings. Bioresour. Technol., 99, 5659-5665. 